\title{
Revisiting Proofreading in Higher Education: Toward an Institutional Response to Editors Canada's Guidelines for Ethical Editing of Student Texts
}

Nina Conrad

Anglosphere universities are a site of growing concern about students' use of professional English language editing and proofreading services for the correction of academic writing. Students' use of such services raises issues of ethics and academic integrity as well as fundamental questions about how value is allotted to the labour involved in producing written texts and providing writing instruction. In addition, the term proofreading is ambiguous, obscuring the extent to which proofreaders intervene in students' written texts. Although much attention has been focused on graduate students' use of proofreading services, there is growing recognition that some undergraduates receive proofreading as well. In response to these issues, Editors Canada (2018) has recently released new guidelines for ethical editing of student texts that, for the first time, delineate standards for professional editing of both undergraduate and graduate students' writing. These guidelines are effective in clarifying acceptable practices for editors, students, and university instructors, yet they apply only to students who seek proofreading from an Editors Canada affiliate. This essay summarizes key considerations in the proofreading debate with the aim of encouraging the development of clearer institutional and classroom policies on proofreading that will complement the Editors Canada guidelines and apply to all students.

Les universités de l'anglosphère s'inquiètent de plus en plus de l'utilisation que font les étudiants et étudiantes de services professionnels de révision et de correction pour leurs textes académiques de langue anglaise. Le recours à de tels services de la part des étudiants soulève des questions d'éthique et d'intégrité académique en plus de questionnements fondamentaux sur l'attribution de la valeur accordée au travail exigé pour la production de textes écrits et l'enseignement de l'écriture. Qui plus est, le terme de correction est ambigu puisqu'il ne permet pas de déterminer dans quelle mesure les correcteurs interviennent dans les textes écrits des étudiants. Si on accorde une attention grandissante au recours des étudiants de cycle supérieur aux services de correction, on reconnaît de plus en plus que certains étudiants de premier cycle y font appel eux aussi. En réponse à ces questions, Réviseurs Canada (2018) a récemment publié de nouvelles directives pour la révision éthique de textes rédigés par des étudiants qui délimitent pour la première fois les normes applicables à la révision professionnelle de textes d'étudiants de premier cycle et de cycle supérieur. Ces normes définissent clairement 
les pratiques acceptables chez les réviseurs, les étudiants, et les enseignants universitaires, mais elles s'appliquent uniquement aux étudiants qui recourent à des services de correction de texte affiliés à Réviseurs Canada. Le présent essai résume les principales considérations du débat sur la correction de texte dans le but de permettre d'offrir aux établissements et aux salles de classe des politiques de correction plus claires susceptibles de compléter les directives de Réviseurs Canada et de s'appliquer à l'ensemble de la population étudiante.

KEYWORDS: editing, proofreading, academic writing, academic integrity

As for-profit English language proofreading services have become readily available via the Internet, there has been growing concern within Anglosphere universities about postsecondary students' use of such services for academic writing. The past two decades have witnessed the emergence of a "discourse of moral panic" (Harwood, 2018, p. 475) around proofreading that foregrounds issues of ethics and academic integrity. The proofreading debate is complex, exposing multiple tensions among students, instructors, and administrators. On the one hand, students may resort to proofreading to compensate for struggles with English and/or academic writing, and there is rising concern that this practice may hinder their development of writing and/or communication skills. On the other hand, the instructional context should be taken into account, as students' engagement in proofreading practices may reflect their adoption of or resistance to the dominant ideologies and power dynamics circulating within their institutions (e.g., Barton \& Hamilton, 2000; Blommaert, Street, Turner, \& Scott, 2007; Clark \& Ivanič, 1997). The debate surrounding students' use of proofreading therefore presents an opportunity for universities to examine the ways in which institutional factors, such as admissions standards, course instructional objectives, provision of on-campus writing support services, and academic integrity policies, may shape students' writing practices and the types of support they come to rely on. The time is ripe for such introspection, as Editors Canada (2018b) has recently released new guidelines for ethical editing of student texts that, for the first time, delineate standards for professional editing of both undergraduate and graduate student texts, reflecting a need for complementary institutional policies that apply to all students.

The aim of this Perspectives piece is to provoke a comprehensive and equitable institutional response to the issue of third-party proofreading in higher education. Toward this end, I draw on research and scholarship on proofreading and academic writing instruction as well as my personal experience of 5 years' employment as a senior editor for an online proofreading firm. In that role, I edited more than 7,000 documents submitted by clients from all over the world, ranging from e-mails a few sentences in length to dissertation manuscripts of hundreds of pages. Although most clients were anonymous to 
me, the types of texts they submitted for editing and the personal information they shared in those texts gave some indication of their demographics if not their identities: Most were postsecondary students writing in English as an additional language. Over time, I developed an interest in the sociopolitical forces that would compel such students to purchase proofreading services for their academic work, and I decided to pursue research on these issues. In the following pages, I summarize key considerations in the proofreading debate and then present further recommendations for universities and instructors on addressing students' use of proofreading in light of Editors Canada's new guidelines.

\section{The Problem of Terminology}

A significant issue underlying the proofreading debate is the ambiguity of the term proofreading itself. In the publishing industry, proofreading refers to a quality check on an already edited manuscript (Editors Canada, n.d.; Matarese, 2016); in other words, it is the final step before a work goes to print. In academic contexts, however, instructors who suggest that students find a proofreader and students who approach academic support centres with requests for proofreading seem to have something else in mind (e.g., Anderson, 2017; Okuda \& Anderson, 2018; Starfield, 2016). In higher education, proofreading may also encompass language or stylistic editing, which involves "clarifying meaning, eliminating jargon, smoothing language and other nonmechanical line-by-line editing" (Editors Canada, n.d.), sometimes with the aim of "eliminating foreign influence" (Matarese, 2016, p. 38). Students or their instructors may even desire a substantive or structural edit, which includes suggestions or changes to organization and content as well (Editors Canada, n.d.). Here, I use the terms edit and proofread interchangeably in reference to third-party corrective interventions in student writing (following Harwood, Austin, \& Macaulay, 2009) and occasionally refer to specific forms of editing.

Inconsistent terminology contributes to much confusion among students, instructors, and even proofreaders over what constitutes an ethical and institutionally acceptable level of intervention in student writing (Harwood, 2019; Kim \& LaBianca, 2018; McNally \& Kooyman, 2017). Examining proofreaders' practices in the U.K. context, for example, Harwood (2018) found great variation in the extent to which 14 proofreaders intervened when given the same master's-level essay. Depths of intervention ranged from individuals who preferred to make comments and refrained from direct corrections to others who effectively rewrote sections of the text-and sometimes introduced errors. In an extension of that study, Harwood (2019) considered the same proofreaders' views on ethical proofreading policies and described a range of perspectives. Some proofreaders adopted a moral stance, arguing that comprehensive proofreading might allow students to submit texts that misrepre- 
sented their actual writing ability. A related concern was that students might not think it necessary to work to develop their writing skills, and they might plateau in their writing ability while becoming dependent on their editors. At the other extreme, some of Harwood's $(2018,2019)$ participants were willing to make more substantial changes, such as to offer suggestions on content and ideas or even to restructure parts of a text, though some expressed doubt over whether these practices were ethical. Given such variation in practices, it is not surprising that proofreading has proven difficult to regulate.

\section{In Pursuit of Writtenness}

To understand students' reasons for using proofreading services, it is necessary to examine the ways in which value is allotted to certain qualities of academic writing. To this end, Turner (2018) has characterized proofreading as a euphemism for the process of attaining writtenness, defined as "the written nature of the text, the culture of evaluation surrounding the quality of the writing, and the wider socio-symbolic effects that this issue has in academic culture" (p. 205). Writtenness thus encompasses both the textual end product and the recognizable labor that has gone into producing it. In academic writing, the presence of writtenness is expected and generally goes unmarked, whereas its absence is likely to be noticed and can be interpreted in any number of ways: as a show of disrespect for one's reader; as resistance to improving one's writing ability or one's English in general; as a poor reflection on one's instructor, supervisor, or institution; or - perhaps most concerningly as an indication of intellectual inferiority (Turner, 2015b, 2018). These concerns are particularly acute at the postgraduate level, where the reputations of research supervisors as well as institutions are linked to students' ability to publish and dissertate (Turner, 2015b). It is thus understandable that the pressure to succeed under such high stakes might compel students to pursue proofreading on their own or when prompted by supervisors.

Such requests do not appear to be limited to graduate students, however. Among 145 students surveyed as part of my recent mixed methods study at a Canadian university, roughly half of whom were undergraduates, about one in five reported that an instructor or supervisor had asked them to have their writing edited, at similar rates among undergraduates as among graduate students (Conrad, 2018). These findings expose an additional tension in the proofreading debate: some instructors' resistance to taking responsibility for helping students to improve their written English. Multiple studies have observed a discursive separation of writing from disciplinary meaning-making in higher education (Starke-Meyerring, Paré, Sun, \& El-Bezre, 2014; Turner, 2012; Woodward-Kron, 2007), which results in the marginalization of "writing work" - that is, the teaching, correction, and assessment of writing (Tuck, 2016). At the undergraduate level, writing work may be afforded relatively low value, unevenly distributed to those of lower status (such as graduate 
students), and therefore resented by instructors or even considered risky to take on in lieu of more highly rewarded (and pleasurable) tasks (Séror, 2009; Tuck, 2016). At the graduate level, research supervisors may take more personal responsibility for their students' writing in recognition that the writing reflects on them as supervisors (Turner, 2015b), yet they may also reach a point of not wanting to correct recurrent errors (Conrad, 2018; Turner, 2015b). At both levels, instructors may lack training on how to teach writing or feel insecure doing so, especially if they have struggled with English or standard written English in their own careers. Even those who recognize the importance of writing - or writtenness - in their disciplines may not want to devote time to writing instruction and feedback (Tuck, 2016). University instructors may view the enforcement of standard written English in particular to be outside their purview, and researchers have documented numerous cases of instructors and supervisors who resisted reading or evaluating students' texts until they had been proofread by a third party (Conrad, 2018; Kettle, 2017; Starfield, 2016). In such cases, the withholding of writing correction may serve to position students as weak writers and/or deficient English speakers who must depend on others to fulfill the writing objectives of their courses or programs.

\section{Scaffold or Crutch?}

Students' use of proofreading raises additional questions regarding the degree to which students take responsibility for their own learning. In 2003, a professor at Simon Fraser University (SFU) ignited a local debate by issuing failing grades to two students who had hired the same tutor to edit their papers for a course in teaching English as a second language (Edgar, 2003; McMartin, 2003; O'Brian, 2003). The tutor had mistakenly returned the same file to both students, who then unwittingly submitted identical papers to the professor. The original author of the paper contested the grade, and a disciplinary panel ruled that the assignment must be regraded. Yet the professor refused to review the paper on moral grounds, arguing that the student deserved an $\mathrm{F}$ for hiring someone to rewrite her assignment.

The incident at SFU gave rise to several arguments that remain relevant today. There is growing concern that by engaging the services of a proofreader, students may evade the responsibility to develop their own writing or language skills (e.g., Scurr, 2006). An additional cause for consternation, especially among those who conceive of writing practices as an aspect of students' academic identity formation, is that students who submit texts for proofreading may relinquish authorial ownership to the proofreader (Myers, 2003). It has also been argued that if a proofreader intervenes directly in a text, then students may not understand why certain changes have been made, they may accept changes without reflection, or they may benefit from the proofreader's own thought process and vocabulary (Harwood et al., 2009; 
Kruger \& Bevan-Dye, 2010; Scurr, 2006). As the owner of an online editing company based in Australia, Lines (2016) observed that some student clients did not even realize that their writing had been edited if the revised version was mistakenly returned to them without tracked changes, a situation I also witnessed several times as an editor. These observations suggest that some students may not be able to spot the nonstandard features in their own writing and, upon receiving a proofread text, may not recognize which features have been edited or the extent of alteration. As a result, they may not realize the amount of work that has gone into proofreading their texts, and they may be disinclined or unable to learn from the proofreader's edits.

The proofreader's degree of familiarity with the student's discipline is an additional consideration. A proofreader familiar with the student's field may intervene too much by providing content-related suggestions or corrections that would be more appropriate from an instructor or supervisor (see, for example, Harwood, 2019), yet a proofreader unfamiliar with the student's field may make injudicious edits that could interfere with the accurate expression of meaning (Harwood, 2018; Turner, 2018). Finally, some academics have complained that students can receive credit for proofreaders' work (Scurr, 2006), which often goes unacknowledged. If there is potential for proofreading to affect students' grades or other academic outcomes, then the ethical dilemma is apparent, and this issue is further complicated if students have paid for such services. Above all, the SFU incident revealed that use of proofreading services occupies a gray area in institutional academic integrity policies, a situation that at some institutions persists more than 15 years later (Conrad, 2018). A curious detail in this case is that the offending students' use of proofreading was detected only because of the tutor's mistake, which raises the question of how often instructors are unaware of their students' use of third-party proofreading.

\section{Proofreading and International Students}

It is likely no coincidence that attention to proofreading in research and the media has grown alongside a dramatic increase in international student enrolment in Canada and globally since the year 2000 (Anderson, 2015) and, in turn, that the use of professional proofreading by international students in particular has been a point of focus in the proofreading debate (Corcoran, Gagné, \& McIntosh, 2018; Harwood et al., 2009; Shaw, 2014; Turner, 2015a). As the higher education system has become increasingly governed by global market forces (Starfield, 2016), public universities in Canada and elsewhere have grown reliant on international students' higher tuition fees as one source to offset decreases in state funding (Anderson, 2015). Within this neoliberal university system, international students are positioned as consumers of education in a global marketplace, subject to discourses of personal responsibility and market-based values in every aspect of their lives (Starfield, 2016). When 
these discourses converge with the marketing of English as a "universal 'basic skill'" (Phillipson, 2017, n.p.) and the valorization of standard written English in higher education (Heng Hartse \& Kubota, 2014), it is unsurprising that some students view an offer to standardize and improve their writing as a worthwhile investment.

Indeed, many in the proofreading industry, including the tutor whose mistake initiated the SFU controversy, have argued that universities have created the very problem of proofreading they now contend with, as declining admissions standards in response to competition for international students have led to offers of admission being extended to students whose writing skills do not yet meet the demands of university-level study (Harwood, Austin, \& Macaulay, 2010; Lines, 2016; see also Starfield, 2016). From this perspective, when universities admit students knowing that they may struggle with academic English upon arrival, they should not then penalize those students for seeking assistance (see also Corcoran et al., 2018). It is worth noting that use of proofreading is not limited to international students; in fact, the majority of participants in my recent study of proofreading at a Canadian university were domestic students who identified as native or near-native English speakers (Conrad, 2018). Nevertheless, international student participants were more likely than their domestic counterparts to find a proofreader online and to pay for proofreading services, indicating that policies on professional editing services may disproportionately affect international students.

\section{The Sticky Subject of Payment}

Further complicating the proofreading debate is the issue of profit. An oftrepeated concern is that students who can afford commercial proofreading services have an unfair advantage over those who cannot (Scurr, 2006). Students' personal finances indeed determine the types of services available to them, as the cost of proofreading is assessed in different ways and varies widely. Many online proofreading firms charge by a combination of word count and deadline, offering turnarounds from just a few hours to a few days or a week. Some also offer multiple service tiers, with the option to receive a more substantive edit at a premium. Others charge by the hour or offer a flat rate for certain types of documents. At rates of a few cents per word, editing services for multiple term papers or an entire thesis manuscript could end up costing a student thousands of dollars (see, for example, Corcoran et al., 2018; Lines, 2016).

My professional experience showed that some clients also get a better return on their investment than others. When price is based on word or page count, proofreading to catch minor typos costs the same as a more substantive edit. And if proofreaders are compensated on commission rather than hourly, they may speed through documents to raise the bottom line. At the firm where I worked, employees were encouraged to aim for 20,000 words 
per day, which required a rapid pace and discouraged thoughtful editing. Some editors complained profusely about being slowed down by error-filled texts, and unfortunately, some passed nasty judgements on such texts' authors. These examples illustrate that in some cases, proofreaders do not respect student clients or their academic goals - an unfortunate downside to the use of online platforms where client and proofreader are anonymous to each other and pay is not directly linked to the quality of proofreading.

\section{Toward a Definitive Approach to Ethical Editing}

Editors Canada's new guidelines for ethical editing of student texts seek to address the multitude of issues surrounding proofreading in the interest of professional editors and their clients. In December 2018, these guidelines replaced the 2006 Guidelines for Editing Theses, which pertained only to doctoral theses. In recognition that use of professional proofreading is not limited to doctoral students, Editors Canada has now produced separate guidelines for undergraduate and graduate student texts, both of which place a renewed emphasis on ethical editing. The aim of both guidelines is to aid students, their instructors or supervisors, and professional editors "to ensure that the work students submit is their own" (Editors Canada, 2018a, 2018c); however, the extent of editing deemed acceptable differs between guidelines.

The purpose of editing for undergraduates, Editors Canada (2018c) emphasizes, is not to improve students' grades. Instead, the guidelines encourage taking a more instructional role: Editors should flag but not fix errors and limit their attention to "grammar, idiom, punctuation, spelling, and mechanics" (Editors Canada, 2018c, p. 2), refraining from stylistic or structural editing. At the graduate level, the guidelines provide more leeway, allowing limited stylistic and structural editing with consent from the student and supervisor. Both guidelines apply to all student work, including term papers and theses at both levels and the addition of journal articles at the graduate level. Neither document pertains specifically to nonnative English-speaking students; both merely point out that most instructors "take the attitude that students seeking degrees from anglophone universities should be able to present and defend their ideas in comprehensible English" (Editors Canada, 2018a, p. 3; 2018c, p. 5), providing a way out for editors who are uncomfortable editing for students with a low level of English proficiency. At the graduate level, however, there is acknowledgement that some supervisors "are more lenient when editing the writing of non-native English speakers, particularly when their research makes a significant contribution to knowledge" (Editors Canada, 2018a, p. 1). Both documents stipulate that students must obtain written permission from an instructor or supervisor to receive editing. To facilitate adherence to the guidelines and help clarify expectations for all stakeholders, Editors Canada has published an accompanying 
permission form that can be adapted for use with students at any level of higher education.

The Editors Canada guidelines offer a timely response to the rise of proofreading in higher education, and at the very least, they should be endorsed by Canadian universities. Yet in many contexts a more comprehensive response is warranted, as the guidelines alone cannot prevent unethical use of proofreading. A serious limitation of the guidelines is that they apply only to professional editing, failing to address students' use of corrective services from other sources, such as friends, family members, academic support services and writing centres, or automated writing checkers. Another unfortunate reality is that students who do not wish to adhere to the Editors Canada guidelines could easily hire an editing provider based outside of Canada. And the required permission form, though well-meaning, is cumbersome for both students and faculty and could discourage students from choosing an Editors Canada affiliate. Overall, the guidelines place too much responsibility for ethical editing on editors and do not hold students accountable for their choice of services. When questions of ethics arise, universities will not have recourse unless they have adopted their own policies on proofreading.

Research has shown that both proofreaders and academic faculty believe the extent of proofreading should be adapted to students' abilities (Harwood, 2019; McNally \& Kooyman, 2017), and therefore a top-down policy may not be the best approach for meeting students' diverse needs. In addition to Editors Canada's blanket policies for undergraduate or graduate students, it may better serve departments and instructors to develop more specific policies in alignment with their instructional objectives as well as local and institutional contexts and exigencies. In this respect, it is worth considering that numerous ideological forces may underlie a student's decision to purchase proofreading. Whether consciously or not, students may be influenced by institutional and societal discourses on language standardization, the privileging of standard English over global varieties, and previous experiences of receiving negative and/or biased assessment of written work. Some students are aware that lexicogrammatical errors may be read as indexical of carelessness, poor education, or intellectual deficit (Conrad, 2018; Davila, 2012; Turner, 2018), and in this sense, their use of proofreading may reflect an empowered choice to control their scholarly image. There may be power imbalances in students' relationships with their instructors or supervisors, and they may also be receiving mixed messages about their writing from instructors with varying orientations to language standards and written corrective feedback. A truly equitable response to proofreading would avoid punitive measures and take these aspects of the sociopolitical context of writing into account.

The idea of students using proofreading cuts to the heart of what it means to be a university English language and/or writing teacher and raises challenging questions about academic integrity, authorship, and language standardization in higher education. It is my hope that the discussion presented 
here will prompt instructors to reflect on this issue in all its complexity in order to address it openly in the classroom. A proactive response is recommended: From the outset, students should receive clear guidance on what types of support will be allowed for coursework and what they are expected to do on their own. Instructors could take a student-centred approach to this task by asking students to analyze hypothetical scenarios about various degrees of third-party involvement in academic writing and facilitating a discussion of what types of intervention are acceptable. Most importantly, classroom proofreading policies should align with instructors' personal values as well as institutional recommendations. By developing policies to complement Editors Canada's guidelines at all levels of the institution, instructors and department administrators can clarify expectations for all stakeholders in the interest of promoting ethical use of support for academic writing.

\section{Acknowledgement}

I would like to thank Meg Lota Brown, Jeroen Gevers, and Sandra Zappa-Hollman for their feedback at various stages of writing this manuscript. I would also like to express my thanks to the anonymous reviewers for their invaluable feedback and encouragement.

\section{The Author}

Nina Conrad is a PhD student at the University of Arizona. Her research interests include academic literacies, language ideologies, and postsecondary students' use of proofreading and literacy brokering in general.

\section{References}

Anderson, T. (2015). Seeking internationalization: The state of Canadian higher education. The Canadian Journal of Higher Education, 45(4), 166-187.

Anderson, T. (2017). The doctoral gaze: Foreign PhD students' internal and external academic discourse socialization. Linguistics and Education, 37, 1-10. https://doi.org/10.1016/j. linged.2016.12.001

Barton, D., \& Hamilton, M. (2000). Literacy practices. In D. Barton, R. Hamilton, \& R. Ivanič (Eds.), Situated literacies: Reading and writing in context (pp. 7-14). New York: Routledge.

Blommaert, J., Street, B., Turner, J., \& Scott, M. (2007). Academic literacies: What have we achieved and where to from here? Journal of Applied Linguistics and Professional Practice, 4(1), 137-148. https://doi.org/10.1558/japl.v4i1.137

Clark, R., \& Ivanič, R. (1997). The politics of writing. London: Routledge.

Conrad, N. L. (2018). Exploring postsecondary students' use of proofreading services at a Canadian university (Master's thesis). University of British Columbia, Vancouver.

Corcoran, J., Gagné, A., \& McIntosh, M. (2018). A conversation about "editing" plurilingual scholars' thesis writing. Canadian Journal for Studies in Discourse and Writing/Rédactologie, 28, 1-25. https://doi.org/10.31468/cjsdwr.589

Davila, B. (2012). Indexicality and "standard" edited American English: Examining the link between conceptions of standardness and perceived authorial identity. Written Communication, 29(2), 180-207. https://doi.org/10.1177/0741088312438691

Edgar, P. (2003, February 1). SFU prof leads fight for tougher English standards. Vancouver Sun.

Editors Canada. (n.d.). Definitions of editorial skills. Retrieved January 20, 2019, from https://www. editors.ca/hire/definitions-editorial-skills 
Editors Canada. (2018a). Guidelines for ethical editing of graduate student texts. Retrieved from https://www.editors.ca/sites/default/files/guidelines_editing_graduatestudenttexts_revised. pdf

Editors Canada. (2018b). Guidelines for ethical editing of student texts. Retrieved from https://www. editors.ca/hire/guidelines-ethical-editing-student-texts

Editors Canada. (2018c). Guidelines for ethical editing of undergraduate student texts. Retrieved from https://www.editors.ca/sites/default/files/guidelines_editing_undergraduatestudenttexts_revised.pdf

Harwood, N. (2018). What do proofreaders of student writing do to a master's essay? Differing interventions, worrying findings. Written Communication, 35(4), 474-530. https://doi. org/10.1177/0741088318786236

Harwood, N. (2019). "I have to hold myself back from getting into all that": Investigating ethical issues associated with the proofreading of student writing. Journal of Academic Ethics. https:// doi.org/10.1007/s10805-018-9322-5

Harwood, N., Austin, L., \& Macaulay, R. (2009). Proofreading in a UK university: Proofreaders' beliefs, practices, and experiences. Journal of Second Language Writing, 18(3), 166-190. https:// doi.org/10.1016/j.jslw.2009.05.002

Harwood, N., Austin, L., \& Macaulay, R. (2010). Ethics and integrity in proofreading: Findings from an interview-based study. English for Specific Purposes, 29(1), 54-67. https://doi. org/10.1016/j.esp.2009.08.004

Heng Hartse, J., \& Kubota, R. (2014). Pluralizing English? Variation in high-stakes academic texts and challenges of copyediting. Journal of Second Language Writing, 24, 71-82. https:// doi.org/10.1016/j.jslw.2014.04.001

Kettle, M. (2017). International student engagement in higher education. Blue Ridge Summit, Pennsylvania: Multilingual Matters.

Kim, E.-Y. J., \& LaBianca, A. S. (2018). Ethics in academic writing help for international students in higher education: Perceptions of faculty and students. Journal of Academic Ethics, 16(1), 39-59. https://doi.org/10.1007/s10805-017-9299-5

Kruger, H., \& Bevan-Dye, A. (2010). Guidelines for the editing of dissertations and theses: A survey of editors' perceptions. Southern African Linguistics and Applied Language Studies, 28(2), 153-169. https://doi.org/10.2989/16073614.2010.519110

Lines, L. (2016). Substantive editing as a form of plagiarism among postgraduate students in Australia. Assessment \& Evaluation in Higher Education, 41(3), 368-383. https://doi.org/10.108 0/02602938.2015.1013919

Matarese, V. (2016). Editing research: The author editing approach to providing effective support to writers of research papers. Medford, NJ: Information Today.

McMartin, P. (2003, January 31). Not all students are literate, tutor says. Vancouver Sun.

McNally, D., \& Kooyman, B. (2017). Drawing the line: Views from academic staff and skills advisors on acceptable proofreading with low proficiency writers. Journal of Academic Language $\mathcal{E}$ Learning, A-145-A-158. Retrieved from http://www.journal.aall.org.au/index.php/jall/article/ viewFile/472/277

Myers, S. A. (2003). Reassessing the "proofreading trap": ESL tutoring and writing instruction. Writing Center Journal, 24(1).

O'Brian, A. (2003, January 29). SFU professor insists an F is an F. Vancouver Sun.

Okuda, T., \& Anderson, T. (2018). Second language graduate students' experiences at the writing center: A language socialization perspective. TESOL Quarterly, 52(2), 391-413. https://doi. org/10.1002/tesq.406

Phillipson, R. (2017). Myths and realities of "global" English. Language Policy, 16(3), 313-331. https://doi.org/10.1007/s10993-016-9409-z

Scurr, R. (2006, December 15). It is not enough to read an essay and mark it: One must also guess if a student has purchased professional help. Times Higher Education Supplement. Retrieved from https://www.timeshighereducation.com/news/ruth-scurr/207185.article 
Séror, J. (2009). Institutional forces and L2 writing feedback in higher education. Canadian Modern Language Review, 66(2), 203-232. https://doi.org/10.3138/cmlr.66.2.203

Shaw, C. (2014, April 9). International students are turning to proofreading agencies to get support. The Guardian. Retrieved from https://www.theguardian.com/higher-educationnetwork/blog/2014/apr/09/international-students-proofreading-academic-writing-support

Starfield, S. (2016). Quotidian ethics in the neoliberal university: Research and practice collide. In P. I. De Costa (Ed.), Ethics in applied linguistics research: Language researcher narratives (pp. 53-65). New York: Routledge. https://doi.org/10.4324/9781315816937

Starke-Meyerring, D., Paré, A., Sun, K. Y., \& El-Bezre, N. (2014). Probing normalized institutional discourses about writing: The case of the doctoral thesis. Journal of Academic Language and Learning, 8(2), A13-A27.

Tuck, J. (2016). "That ain't going to get you a professorship": Discourses of writing and the positioning of academics' work with student writers in UK higher education. Studies in Higher Education, 41(9), 1612-1626. https://doi.org/10.1080/03075079.2014.999320

Turner, J. (2012). Academic literacies: Providing a space for the socio-political dynamics of EAP. Journal of English for Academic Purposes, 11(1), 17-25. https://doi.org/10.1016/j.jeap.2011.11.007

Turner, J. (2015a). Academic literacies at the institutional interface: A prickly conversation around thorny issues. In T. Lillis, K. Harrington, M. R. Lea, \& S. Mitchell (Eds.), Working with academic literacies: Case studies towards transformative practice (pp. 375-381). Fort Collins, Colorado: WAC Clearinghouse and Parlor Press. Retrieved from https://wac.colostate.edu/ books/lillis/chapter28.pdf

Turner, J. (2015b). The symbolic economy of research literacies: The role of "writtenness" in the $\mathrm{PhD}$ thesis. In C. Badenhorst \& C. Guerin (Eds.), Research literacies and writing pedagogies for masters and doctoral writers (pp. 205-220). Leiden: Brill.

Turner, J. (2018). On writtenness: The cultural politics of academic writing. New York: Bloomsbury.

Woodward-Kron, R. (2007). Negotiating meanings and scaffolding learning: Writing support for non-English speaking background postgraduate students. Higher Education Research $\mathcal{E}$ Development, 26(3), 253-268. https://doi.org/10.1080/07294360701494286 